\title{
The implementation of human resources information system and it's benefit for organizations
}

\author{
LIELI SUHARTI ${ }^{1}$ and PRIYANTO RATNA SULISTYO², \\ ${ }^{1}$ Magister Management Program, Faculty of Ecomonics and Business, Satya Wacana Christian University, Indonesia
}

\begin{tabular}{ll}
\hline Abstract & The objective of this study is to examine the effect of the implementation of the Human \\
& Resources Information System (HRIS) on time efficiency, cost efficiency, quality of \\
information, and managerial satisfaction. Using data of 80 respondents who are managers \\
and staff working in HR department of companies in Central Java and Yogyakarta, we find \\
that the implementation of HRIS affects time efficiency and managerial satisfaction. \\
However, our study also find that the hypothesis concerning that the implementation of \\
HRIS affects cost efficiency and quality of information is not supported.
\end{tabular}

Keywords Implementation of HRIS, time efficiency, cost efficiency, quality of information, managerial satisfaction.

\section{INTRODUCTION}

Information technology has a role in bringing fundamental changes to both private and public organizations, and it can also improve the performance of the organization (Devaraj and Kohli, 2003). One of the widely used system by companies nowadays is the Human Resources Information System (HRIS). HRIS is used to manage human resources in the company as a form of application data and human resource information in a more structured way to support the role of HR as Administrative Expert (Lengnick et al., 2003).

As already noted by Hendrickson (2003), Dery and Wiblen (2009), HRIS is a system which is developed with an integrated technology to collect, store, and analyze information related to people in the organization. HRIS implementation involves databases, computer applications, hardware and software that are used to store, manage, record, deliver and manipulate data for various functions of human resource interests. Troshani, Jerram \& Hill (2011) added that the HRIS has become something that is very important to help businesses/ organizations to manage human resources more effectively.

The role of HRIS is increasingly important for the company from time to time. A US study showed that $70 \%$ of large companies use HRIS, $80 \%$ use recruitment online, $67 \%$ open job vacancies online, and $40 \%$ use the web-based portal as a means to communicate the company policies to their employees (Grobler et al., 2006 ). While in Indonesia, since 2002 companies in Indonesia have started using HRIS for the management of human resources.

Investment in the IT field is a big investment. Therefore, the implementation of Information technology should also pay attention to its benefits (Hendricks and Stratman, 2007; kumar, 2012; Sikha \& Karishma, 2012). Orlando and Johns (2004) asserted that the implementation of HRIS that used advanced information management system needs to be continued with the activities of monitoring the positive and negative impacts that appeared. Dewayani (2011), in her research on the implementation of the HRIS in Indonesian companies, found that the HRIS implementeration in Indonesia has been consistent with the goals of the company. HRIS Implementation affects employee empowerment in the company, but it was found that some of the processes and methods of HRM practices have been able to be implemented online, so that they support the smoothness of the employee's working activities. 
A number of other previous studies found a variety of benefits as a result of the implementation of HRIS for the organization. HRIS has been predicted to positively affect time efficiency because by implementing HRIS in the organization, employees can input data more quickly, accurately and efficiently. A survey that was conducted by Overman (1992) found some advantages in using HRIS, such as the companies can be faster in processing information, the information can be processed more accurately, improve planning, and improve the communication with employees.

Another benefit of the implementation of HRIS in organizations is the cost savings or cost efficiency. Brown (2008), gave the example of IBM using the new system providing online data for employees, and for the company it saves $\$ 1.2$ million per year in the terms of printing and administration cost.

Dorel and Bradic (2011) in their research found that the use of HRIS influences the quality of information, as a factor in the successful implementation of HRIS. Ball (2001) revealed that the use of HRIS can improve the managerial satisfaction due to the quality of the system and the quality of information on the use of HRIS. With an effective HRIS, it will ultimately help HR processes to be more efficient and faster, thus will have an impact on managerial satisfaction. Conversely, if HRIS is not implemented properly and effectively, HRIS can fail to bring organizational managerial satisfaction. Aside from the administrative aspect, according to Johnson and Gueutal (2011), HRIS can make employee data that has greater coverage and wider access as well. It can have an impact on menajerial satisfaction which depends on the system.

Based on the background above, this study aims to examine the effect of the implementation of HRIS towards time efficiency, cost efficiency, quality of information, and managerial satisfaction in the companies that have implemented HRIS in Indonesia.

\section{LITERATURE REVIEW AND HYPOTHESES DEVELOPMENT}

\section{Human Resources Information System (HRIS)}

HRIS is a part of the Management Information System, is a group of several systems that contain and provide a lot of information that support the management of a company (Wu, 1984). McLeod and Schell (2007), added that the HRIS is defined as a system that provides information for managers thoroughly about the organisation's human resources.

According to Altarawneh and Al-Shqairat (2010), HRIS is a concept that has a focal point on the utilization of information technology development as the functional manager in Human Resources Management (HRM). According to Ruel, Bondarouk \& Looise (2004), an organization needs to develop an information system to support the management of human resource in order to assist in strategic decision makings.

Generally, the purpose and benefits of the implementation of HRIS in the company/organization is to improve services for employes and managers. According to Shani and Tesone (2010), some benefits of HRIS on the Human Resources Management (HRM) are; (1) saving on cost and time, (2) contribution in making strategic decision, (3) improving the quality of strategic decisionmaking, and (4) increase in the commitment for employee development. Besides the benefits of the administration and the strategic use of HRIS above, Beckers and Bsat (2002) revealed five reasons why companies need to implement the HRIS as follows: (1) HRIS can improve competitiveness by improving the practice of the HR, (2) HRIS produces a number and various operational HR which are greater, (3) HRIS can shift the focus of conventional HR to the management of human resources that are strategic, (4) HRIS considers employees as the assets of the company, and (5) HRIS can reengineer the entire function of $\mathrm{HR}$.

\section{The influence of HRIS on time efficiency}

Time efficiency is the process of getting things done faster by working smarter (Davidson, 2001). The purpose of HRIS implementation is to process large amounts of data with high accuracy, thereby preventing employees from doing these activities manually. Thus, the time needed to work will be more cost-effective and more efficient in its use.

Furthermore, according to Beadles et al., (2005) and Kovach et al,. (2002), strategically HRIS imlementation can improve the quality and the speed of management decision making. The process of information delivery will be faster, and the accuracy of the 
information will be more secure. In their study, Karikari and Ocansey (2015) found that HRIS can save time and efficiency by merging the HRIS application with the website, the organizations can do online recruitment, so that the speed of time can run efficiently and the job activities can be faster. Kovach et al., (1999) and David et al., (2015) also said the same thing, that the generally recognized benefits of the use of HRIS is able to reduce time for the administrative processes.

\section{H1: HRIS Implementation has a positive effect on time efficiency}

\section{The effect of HRIS on cost efficiency}

An HRIS system is a big investment decision for the company. Pandya (2013) stated that the implementation of HRIS will reduce HR costs through the automation of information. Beadless et al., (2005) also said that HRIS creates efficiencies of information that enables HR managers to turn their attention to provide better data analysis.

The general benefits of HRIS in the study conducted by Lederer (1984) revealed that HRIS can improve the accuracy of right and quick information access availability and cost savings. Lori and Elaine (2002) in their study of found that the implementation of HRIS helps cutting the costs by $90 \%$ by using online recruitment, thus it can save the cost efficiency.

H2: HRIS Implementation has a positive effect on the cost efficiency

\section{The influence of HRIS on quality of information}

The implementation of HRIS provides data and information flows that allow more effectively decision making process. The dimension of quality of information includes the quality of data in which the accuracy of objectivity and reputation is necessary. In addition, in the terms of contextual relevance, added value, the completeness of the amount of data greatly affects the ease of one's understanding in receiving the information available (Lori \& Elaine, 2013). Therefore, the data and information collected through HRIS must be accurate and qualified.

HRIS can reduce redundancy in the organization because of the centrality of information and easy accessibility. It also enhances the ability to create reports and analyze information quickly and accurately, thus it makes the workforce easier to manage (Lucerna, 2013). According to Mahdi Mahmoudi (2008), one of the advantages is the use of HRIS can develop the quality of reporting. The relationship between HRIS and quality of information is mutually sustainable, as found by Beadles et al., (2005) that HRIS has a positive but moderate relationship on quality of information.

H3: HRIS has a positive effect on the quality of information

\section{The influence of HRIS on managerial satisfaction}

An effective HRIS aims to make HR processes more efficient and faster, thus it can have an impact on managerial satisfaction. However, if it is not properly and effectively implemented, HRIS may fail to bring managerial satisfaction. Managerial satisfaction in using HRIS systems can be improved when there is an efficiency of the entire decision making improvement, costs reduction, and the improvement of the budget control, business transparency, a clear vision of the business organization, and a clear understanding in HRM practices (Dorel \& Bradic- Martinovic, 2011).

Johnson and Gueutal (2012) stated that the HRIS provides access to information that can improve the transparency of the process of HR, helping to better understand the role of $\mathrm{HR}$ in the organization, and has control over the information that may increase the sense of justice and job satisfaction. Ball, et al., (2012) in their research revealed that the application of HRIS in an organization can provide managerial satisfaction is influenced by the quality of the system and the quality of information.

H4: HRIS Implementation has a positive influence on managerial satisfaction.

\section{METHODS}

The population in this study are HRD managers and staff of the companies in Central Java and Yogyakarta implementing HRIS. From 100 questionnaires distributed, only 80 responded. Of the respondents of our study, $72.20 \%$ are male and the majority $(45 \%)$ are $30-40$ years old. $80 \%$ of respondents have a formal Bachelor's and 
Master's Degree. The majority of our respondents' working tenure is ranging from $5-10$ years $(62.2 \%)$ and the implementation of HRIS in the majority of companies are 5-10 years and more $(62.5 \%)$.

The measurement of this study variables used Likert scale with the answer of 1 (strongly disagree) to 5 (strongly agree). The empirical indicator of the research scale used a scale that has been developed from the previous studies. HRIS Implementation used a scale developed by Lengnick-Hall and Moritz (2003) consisting of 6 items of questions; The Measurement of Time Efficiency, Cost efficiency, and managerial satisfaction used a scale from Beadles, Jones and Lowery (2005) with each of the six questions; The variables measurement of Quality of information using a scale LengnickHall and Moritz, (2003) with 5 questions.

In this study, the data analysis was done gradually. Before the researcher tested the hypotheses, the data validity was tested by using the validity and reliability tests. Furthermore, the classic assumption test including normality test, Multicollinearity Test, and Heterocedastity Test were done. This was followed by hypothesis testing by using multiple regression test with SPSS 16 software.

In this study, all empirical indicators from studied variables were declared as valid because it has a value of corrected item-total correlation that is 0.3 or higher. Furthermore, the reliability test results show that all of the variable has a value of Cronbach Alpha > 0.60 , so that it can be stated all the variables are reliable. The result of classic assumption test shows that the data of this study was normally distributed, and there was no multicolinearity between the study variables, and there was no heteroscedasticity.

\section{RESULTS}

From the results of the regression test that was conducted on those four hypotheses of this study, the results are summarized as showed in table 1 .

From the regression analysis, it shows a number of elements of a HRIS implementation variables that affect the time efficiency and managerial satisfaction, it was shown by the sig value that is smaller than 0.05 , but for the hypothesis related to cost efficiency and quality of information in this study, it does not have any effects (sig value $>0.05$ ). The value of $R$ square for the two accepted hypotheses shows the numbers of 0.274 and 0.263 which mean that the variables in this research model only contribute about $26 \%$ and $27 \%$. The rest is influenced by other factors which were not examined.

\section{DISCUSSION}

Based on the results of the hypothesis test, this study found that HRIS has a significant effect on the time efficiency. This is supported by descriptive statistics data from the study, the respondents agreed that the implementation of HRIS makes time efficiency increase, so as to complete tasks and work more on time. With the implementation of HRIS, online recruitment, the completion of the administrative tasks are already systematically structured, so it helps to finish the work more easily. HRIS role has contributed greatly to the efficiency of administration time, as well as the role of technology also helps to reduce the time in the decision making process.

The results of this study support the findings of a research conducted by Kovach et al., (1999), and Troshani \& Hill (2011) whoich found that HRIS can save time and efficiency by merging the HRIS application to the organization's website, through online recruitment, so that the speed of time can run efficiently and working activities can be done faster. This finding is also consistent with research by Reddick (2009) with findings suggested that if an HR management is integrated with information system, it can help in saving time for HR process, such as recruitment.

Hypotheses test results also show that HRIS Implementation influence the managerial satisfaction. This is in line with a research conducted by Johnson and Gueutal (2011) which found that the implementation of HRIS provides information access that is more transparent, and helps the management to understand the role of $\mathrm{HR}$ in the organization better. It is believed to make them feel that they have control over the information and may lead to increase the sense of justice and job satisfaction. These findings also support the research conducted by Dewayani (2011) who found that the implementation of HRIS system affects on the employee's job activities, thereby increase the employee satisfaction. 
Table 1

Summary of Hypotheses Test

\begin{tabular}{cccccc}
\hline $\begin{array}{l}\text { Dependent } \\
\text { Variables }\end{array}$ & Hypotheses & T Value & Sig & $\begin{array}{l}\text { R } \\
\text { Square }\end{array}$ & Result \\
\hline $\begin{array}{c}\text { Time } \\
\text { efficiency }\end{array}$ & $\mathrm{H} 1$ & 2,521 & 0,014 & 0.274 & Accepted \\
\hline $\begin{array}{c}\text { Cost } \\
\text { efficiency }\end{array}$ & $\mathrm{H} 2$ & 1.336 & 0,186 & 0.150 & $\begin{array}{c}\text { Not } \\
\text { Accepted }\end{array}$ \\
\hline $\begin{array}{c}\text { Quality of } \\
\text { Information }\end{array}$ & $\mathrm{H} 3$ & 1,645 & 0,147 & 0.164 & $\begin{array}{c}\text { Not } \\
\text { Accepted }\end{array}$ \\
\hline $\begin{array}{c}\text { Managerial } \\
\text { Satisfaction }\end{array}$ & $\mathrm{H} 4$ & 2.473 & 0.012 & 0.263 & Accepted \\
\hline
\end{tabular}

Furthermore, the hypotheses which claims that there is an influence of HRIS implementation on the cost efficiency is not supported in this study. It is not in line with research conducted by Beadless et al., (2005) and Lori \& Elaine (2002) which showed that there is an effect of HRIS on cost management. Nevertheless, this study is consistent with results of a research conducted by Karikari et al., (2015) that the implementation of HRIS does not impact on the costs of recruitment, training and development of employees. In addition, when it is viewed from the development high initial cost and maintenance cost of of HRIS system, the return on investment costs required at least up to eight years (Shani \& Tesone, 2010). In the research, the majority of companies studied just applied HRIS between 5-10 years, so there is a possibility that the investment cost of HRIS has not given a benefit higher than the cost which has been paid.

The hypothesis that HRIS can influence the quality of information is not supported in this study. This is not correspond with a research conducted by Lucerna (2013) who found that HRIS can improve the quality of information, so it can make the employee to be more easy in managing the data. However, this study is consistent with a research held by Ankrah, et al., (2012), which stated that the implementation of HRIS does not have too significant impact on the quality of information. The argument can be put forward to explain it is that there is potential errors caused by humans, such as data input errors, or technical errors that may affect the accuracy of the information data.

\section{CONCLUSION}

Based on the results, our research conclude that HRIS implementation is verified to affect the time efficiency. Our research also shows that HRIS implementation is not the determinat of cost efficiency. Furthermore, it can be conclude that HRIS Implementation does not affect the quality of information. Last, it can also be concluded that HRIS implementation affects the managerial satisfaction.

\section{Limitations and future research suggestions}

This study focuses only on HRD managers and staff in companies in Central Java and Yogjakarta. Therefore, the research results have limitations in terms of generalization of conclusions. For future research, it can be expanded to the broader range of research objects to strengthen the notion of this research notion.

In this research, the difference of business sector and business scale is not analyzed. For future research, this research model can be tested on different business sectors and business scale.

The research model can be developed by adding other variables that can act as moderating or mediating variables, such as organizational culture, leadership roles, supporting facilities, and others.

\section{REFERENCES}

Altarawneh, I., and Al-Shqairat, Z. (2010). Human Resource Information Systems in Jordanian Universities. International Journal of Business and Management, 5(10), 113-127. 
Ankrah, Ebenezer \& Evans Sokro. (2012). Human Resources Information System as A Strategic tool In Human Resources Management. Problems of Management in The 21th Century Vol 5.

Ball, K. (2001). The Use of Human Resource Information Systems: a Survey. Personnel Review, 30 (6):667-693.

Beadles, N., Lowery, C. M., \& Johns, K. (2005). The Impact of Human Resource Information Systems: An Exploratory Study in the Public Sector. Communications of the IIMA 39, 5 (4).

Beckers, A. M., \& Bsat, M. Z. (2002). A DSS classification model for research in human resource information systems. Information Systems Management, 19(3), $1-10$.

Brown, S. (2008). Human Resource Information Systems. CompareHRIS.com

David, Dr Shine, Naina Chopa, Sachin Batham. (2015). The Human Resources Information System Productiveness in Organizational Culture and Its Importance. International Journal Of Core Engineering \& Management (IJCEM) Volume 2.

Davidson. (2001). Microsatellite DNA Methodology. New York City: Davidson College.

Dery, K., Grant, D. \& Wiblen, S. (2009). Human Resource Information Systems: Replacing or Enhancing HRM. 15th World Congress of the International Industrial Relations Association IIRA 2009. The New World of Work, Organisations and Employment, Sydney, Australia, 27 August 2009.

Dewayani, Eka Kadharpa Utama. (2011). Implikasi Human Resource Information System Pada PT. TELEKOMUNIKASI INDONESIA, TBK. Malang: Jurnal Manajemen Bisnis Volume 1 No. 2.

Devaraj, S. and Kohli, R. (2003). "Performance Impacts Of Information Technology: Is Actual Usage The Missing Link? "Management Science.

Docksai, R. (2011). Computers making the Quantum Leap. Futurist, 45(3), pp. 10-11.

Dorel, D. \& Bradic-Martinovic, A. (2011). The role of information systems in human resource management. Munich Personal RePEc Archive (MPRA). Paper No. 35286.

Grobler, P., Warnich, S., Carrell, M., Elbert, N. \& Hatflied, R. (2006). Human Resource Management in South Africa. 3rd Edition. London: South-Western.

Hendricks, K., Singhal, V., Stratman, J., (2007), "The Impact of Enterprise Systems on Corporate Performance A Study of ERP, SCM, and CRM System Implementations"

Hendrickson, A. R. (2003). Human Resource Information Systems: Backbone Technology of Contemporary Human
Resources. Journal of Labor Research, 24(3): 381-394.

Karikari, A.F., Boateng, P.A. and Ocansey, E.O.N.D. (2015). The Role of Human Resource Information System in the Process of Manpower Activities. American Journal of Industrial and Business Management, 5, 424-431.

Kovach, Kenneth A. \& Cathcart, Jr., Charles E. (1999). Human Resource Information Systems (HRIS): Providing Business with Rapid Data Access, Information Exchange and Strategic Advantage. Public Personnel Management. 28( 2), 275-282.

Kovach, K. A., Hughes, A. A., Fagan, P., Maggitti, P. G. (2002). Administrative and strategic advantages of HRIS. Employment Relations Today, 29 (2), 43-48.

Kumar, R. (2012). Human Resource Information System: An Innovative Strategy for Human Resource Management. Gian Jyoti E-Journal, 1(2), 1-12.

Lederer, A. L. (1984). Planning and developing a human resource information system. The Personnel Administrator, 29 (8), 27-39.

Lengnick-Hall, Mark L., \& Moritz, S. (2003). The Impact of e-HR on the Human Resource Management Function. Journal of Labor Research, 24 (3), 365-379.

Lori, B. \& Elaine, D. (2002). Information Systems: The quiet revolution in Human Resource management. The Journal of Computer Information Systems, 42 (2), 17-20.

Lucerna, L. L. C. (2013). HR Payroll Solutions. HRIS Software.

Mcleod, Raymond dan Schell. (2007). Sistem Informasi Manajemen. Edisi 9. Jakarta: PT Index.

Ngai, E.W. and Wat, F.K. (2006). Human resource information systems: a review and empirical analysis. Human Resource Information Systems, 35, 298-314.

Orlando, R. and N. B. Johns. (2004). "High performance work practices and human resource mangement effectiveness: substitutes of complements? .Journal of Business Strategies 21 (2): 133-148.

Overman, S. (1992). Reaching for the 21st Century. HR Magazine, 37, 61-63.

Johnson, R. D. \& Gueutal, H. G. (2011). Transforming HR through technology: The use of eHR and human resource information system in organisations. SHRM Effective Practices Guidelines Series.

Pandya, A. (2013). The impact of Human Resource Information System.

Reddick, C.G., (2009). Human Resources Information System in Texas City Government: Scope and Perception of Its Effectiveness. Public Personnel Management, 38 (4): 19-34. 
Ruel, H., Bondarouk, T., \& Looise, J. K. (2004). EHRM: Innovation or irritation: An explorative empirical study in five large companies on webbased HRM. Management Review, 15(3), 364-380.

Shani, A. \& Tesone, V.D. (2010). Have Human Resource Information systems evolved into internal e-commerce? Emerald Group Publishing Limited, 2(1),30-48

Shikha N. Khera \& Karishma Gulati. (2012). "Human Resource Information System and its impact on Human Resource Planning: A perceptual analysis of Information Technology companies". India
Troshani, I., Jerram, C., \& Hill, S. R. (2011). Exploring the public sector adoption of HRIS. Industrial Management \& Data Systems, 111(3), 470-488.

Wu. Frederick H.(1984). Accounting Information System Theory and Practice. 